\title{
Genetic use restriction technologies and possible applications in the integrated pest management
}

\author{
Tecnologias genéticas de restrição de uso e possíveis \\ aplicações no manejo integrado de pragas
}

\author{
Giliardi Dalazen $^{I^{*}}$ Aldo Merotto Júnior ${ }^{\mathrm{I}}$
}

\section{- REVIEW -}

\section{ABSTRACT}

Genetic use restriction technologies (GURTs) were developed to preserve the intellectual property of genetically modified crops (GM) and ensure the return of investments made by industry to obtain technology delivered through seeds. The aims of this review are to discuss the GURTs and analyze their possible applications in integrated management of agricultural pests. There are two classes of GURTs: T-GURTs (trait-based GURTs), wherein the generated seed are viable, but the next generation does not express the trait of agronomic interest, and V-GURT (variety-based GURTs), in which plants produce non viable seeds. However, beyond the seed protection purpose, the GURTs could have also other application to solve agronomic problems. One of the most important is the use of GURTs as a tool to restrict gene flow of GM traits to relative weeds. In addition, it is proposed the use of this technology in integrated weed management by preventing the GMs seed germination, which produces volunteer plants that compete with the crop of interest. Also, these volunteer plants may serve as alternative hosts for insects and pathogens in between crop seasons. The GURTs could contribute to the control of undesirable agents in agricultural systems, reducing the use of pesticides and increasing crop yields.

Key words: terminator technology, GURT, LEA promoters, IPM, crop protection.

\section{RESUMO}

As tecnologias genéticas de restrição de uso (GURTs) foram idealizadas a fim de preservar a propriedade intelectual de culturas geneticamente modificadas (GMs) e garantir o retorno dos investimentos feitos pelas empresas para a obtenção de tecnologias transmitidas via sementes. Os objetivos dessa revisão são discutir as GURTs e analisar suas possiveis aplicações no manejo integrado de pragas agrícolas. Existem duas classes de GURTs: a T-GURT (trait-based GURT), na qual as sementes produzidas são viáveis, porém as plantas da geração seguinte não expressam o caractere de interesse agronômico, e a V-GURT (variety-based GURT), na qual as plantas produzem sementes inviáveis. Contudo, além do propósito da proteção das sementes, o uso de GURTs poderia também ter outras aplicações na resolução de problemas agronômicos. Um dos mais importantes é o uso das GURTs como ferramenta para impedir o fluxo de genes de culturas transgênicas para plantas daninhas coespecificas. Além disso, propõe-se o uso dessa tecnologia no manejo integrado de plantas daninhas, por meio da prevenção da germinação de sementes GMs, que geram plantas voluntárias que competem com a cultura de interesse. Além disso, essas plantas voluntárias podem servir como hospedeiros alternativos para insetos e patógenos nos periodos de entressafra. Dessa forma, as GURTs poderiam contribuir no controle de agentes indesejáveis em sistemas agrícolas, reduzindo a utilização de agrotóxicos e aumentando a produtividade dos cultivos.

Palavras-chave: tecnologia terminator, GURT, promotores de LEA, MIP, proteção de plantas.

\section{INTRODUCTION}

Genetic use restriction technologies (GURTs), also known as terminator technologies, were developed with the aim to restrict the access to genetic materials and their phenotypic traits (VAN ACKER et al., 2007). There are two major classes of GURT: V-GURT (variety-based GURT) and T-GURT (trait-based GURT). The V-GURT restricts the use of the variety through blocking the plant reproduction via production of non-viable seeds. Conversely, the T-GURT regulates the expression of certain genes that confer desirable agronomic traits, such as stress tolerance, pest resistance (insects and diseases) and

IDepartamento de Plantas de Lavoura, Faculdade de Agronomia, Universidade Federal do Rio Grande do Sul (UFRGS), 91540-000, Porto Alegre, RS, Brasil. E-mail: giliardidalazen@gmail.com. "Corresponding author 
herbicide resistance (PENDLETON, 2004). Plants carrying T-GURT produce viable seeds, but the offspring did not express the transgene of interest.

The initial restricted germination technology was created based on the V-GURT class in order to generate plants that produce sterile seeds, preventing its use in successive generations. The original patent, registered in 1998 entitled "Control of gene expression" (US Patent 5,723,765) was developed to prevent the unauthorized use of seeds from new crop varieties (OLIVER et al., 1998). Seed companies' owning cultivars with some traits of agronomic interest, such as tolerance to the herbicide glyphosate (e.g. GR soybeans), would guarantee the return on investment via seed marketing. However, the great popular pressure on Monsanto, leading developer company of genetically modified crops (GM), was essential to interrupt the introduction of this seed germination control technology in late 1990's (NIILER, 1999).

After a period of approximately 15 years of forgetfulness, the discussions about the use of GURTs have recently been restarted. Recent judicial decision against the payment of royalities could have made seed companies direct their efforts to use GURTs in commercial varieties (LEDFORD, 2013). For example, there are requests for the legalization of GURTs research in Brazil in the agenda of the National Biosafety Technical Commission (CTNBio) (CTNBio, 2014), since they are prohibited in the country by Biosecurity Law No. 11.105, March 24, 2005.

In addition to the main purpose of the GURT discussed above, this technology could also be applied to help solve agricultural problems beyond the interests of the holding companies. Thus, the aims of this review are to discuss the GURTs technologies and analyze their possible applications in integrated management of agricultural pests.

\section{Classes of GURTs}

The differences between the two classes of GURTs consist in particularities regarding the development and utilization. V-GURT (variety-based GURT) restricts the use of the variety as a whole by blocking its reproduction. T-GURT (trait-based GURT) regulates the expression of a particular trait. The V-GURT could be considered the most drastic, since it produces non-viable seeds. For this reason, V-GURT was named as Terminator Technology or "suicide seeds" (VAN ACKER et al., 2007).

\section{V-GURT (variety-based GURT) or Terminator Technology}

The V-GURT technology is based on transferring a genetic construct that comprises three genes (Figure 1) (VAN ACKER et al., 2007). The first gene encodes a protein that suppresses the second gene, a recombinase gene. A recombinase gene encodes a protein with recombinase activity, which cleaves the blocking sequence linked to the toxic gene by means of a repressor compound produced by a third gene. The third gene is the terminator gene itself, since it encodes a toxic substance. The terminator gene is linked to a blocking sequence that prevents its activation. However, the lethal activity of the construct depends upon an external stimulus, such as application of the antibiotic tetracycline, which is applied by the company via seed treatment before sale. This substance will block the binding of repressor to the promoter, resulting in activation of the recombinase gene. In the absence of the application of stimulus, the repressor compound prevents the action recombinase gene of been activated and thus the blocking sequence of the toxic gene remains inactive. Thus, without applying the external stimulus, plans remain fertile and produce viable seeds (Figure 1A). However, when applying the external stimulus to the seeds, the recombinase gene is activated and occured the removal of the blocking sequence of the terminator gene, resulting in its expression. Thus, there is the production of toxic substances to the embryo, resulting in unviable seeds (Figure 1B). In another proposal of VGURT, exposure to tetracycline serves as an inhibitor of the terminator gene. In this type of V- GURT the repressor gene is suppressed, permitting the expression of the gene terminator. The application of the external agent (tetracycline) activates the expression of the repressor gene, whose product represses the expression of the terminator gene. Although the system is different, the end resulted is the same, resulting in the production of sterile seeds (PENDLETON, 2004). Except for the character of seed viability all other plant traits remain unchanged including grain yield and dry matter (LEHMANN, 1998).

The promoter of late embryogenesis abundant proteins (LEA) is used to control the terminator gene. These proteins act in response to a variety of stresses, such as drought, salinity, cold, osmotic stress, freezing (BATTAGLIA \& COVARRUBIAS, 2013). All these stresses have the common characteristic of causing water stress. As a consequence of that, the LEA proteins, which are highly hydrophilic, accumulate in plant tissues during drought periods (BATTAGLIA et al., 2008; BATTAGLIA \& COVARRUBIAS, 2013). However, these proteins are not only associated to water deficit caused by environmental changes but also to water limitation produced during plant development, such as development of seeds and pollen grains even in normal growth conditions (SHEORAN et al., 2006). Furthermore, these proteins accumulate in the desiccation-resistant structure of dormant seeds 


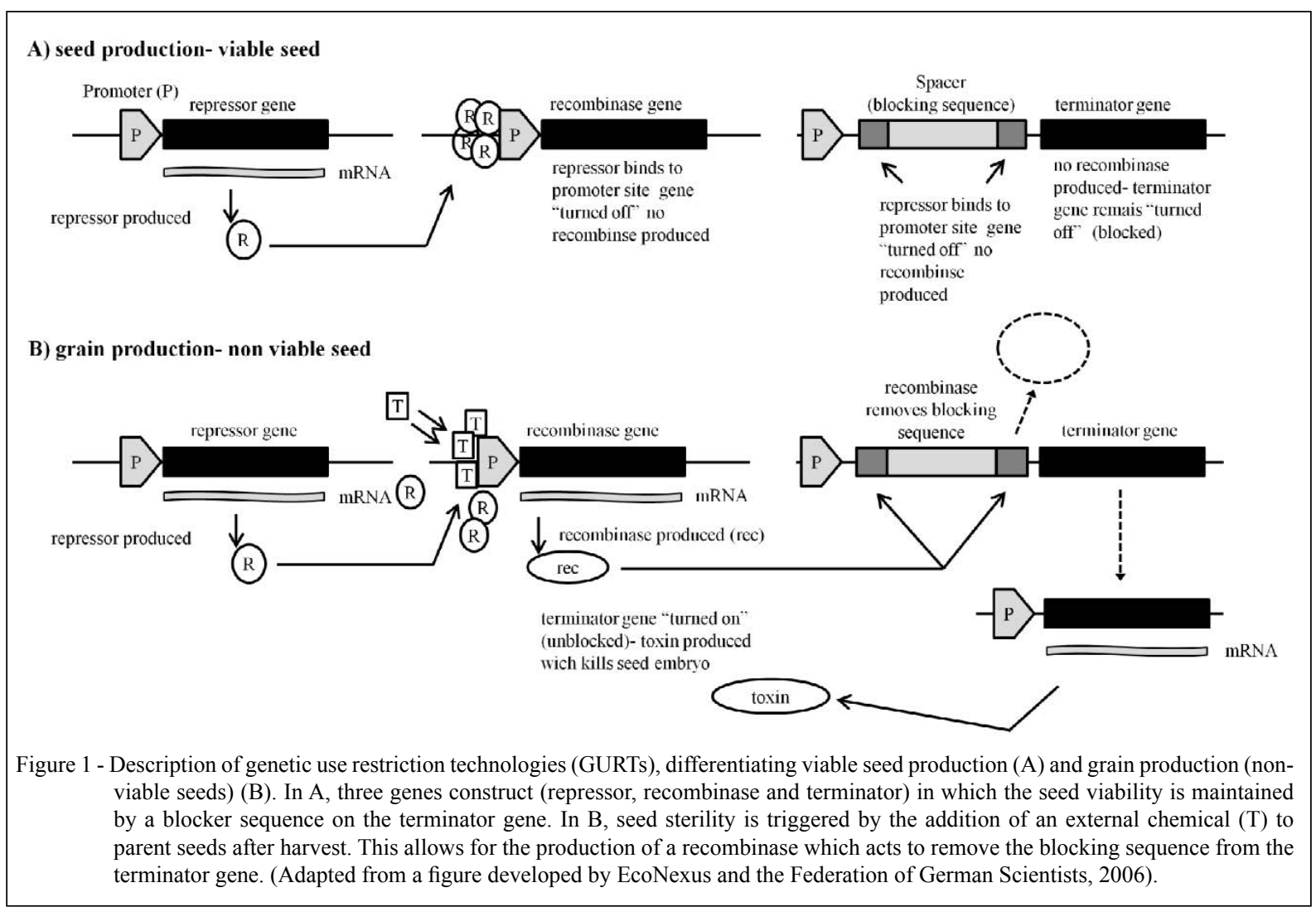

embryos making them able to withstand for long periods in the absence of water (BIES-ETHÈVE et al., 2008). The LEA promoters act in late embryogenesis, in the pollen and seeds production period, when the lack of water could be lethal. For this reason LEA promoters are used in constructs of GURT, since its expression occurs during embryogenesis, just as the terminator gene should act.

The terminator gene encodes an inhibitory ribosome enzyme, called RIP (Ribosome Inactivating Proteins). The RIP proteins produce toxic substances, which inhibit the activity of ribosomes (mRNA translation), not allowing the synthesis of proteins essential for the formation of the embryo in seeds (STIRPE, 2004). Thus, due to incomplete formation of the embryo, the seed of plants with the construct V-GURT are sterile.

\section{T-GURT (trait-based GURT)}

In T-GURT plants one or more genes conferring certain traits are activated by application of a chemical triggering agent. This agent, called key, will inhibit the repressor action over the recombinase gene, allowing its expression, which will unlock the expression the gene of interest. Thus, to make use of this technology, farmers must pay for the chemical that acts as an external agent. In T-GURT the holders of the intellectual property will make revenues through selling the external agent (VAN ACKER et al., 2007). In this technology, seed market is not related with the royalties payment, since the farmer cannot make use of the desirable trait, even considering that it is included in the plant genome (DANIELL, 2002; PENDLETON, 2004).

Practical applications of GURT in weed management The discussion about legalization of GURTs is based on the main issues of food security and biological and environmental effects that would be addressed to the seed companies. These companies aim to obtain royalties related with the intellectual property of transgenic products. However, the use of this technology can also bring benefits to agriculture. Some applications of this technology are presented hereafter.

\section{Containment of transgenes flow}

The gene flow among crops and relative weeds is a threat that has been underestimated in several situations (WARWICK et al., 2009; GOULART et al., 2012). Gene flow occurs as a 
consequence of the viable pollen dispersal and spread of seeds, which could grow and produce pollen and seeds for a new dispersion event (DANIELL, 2002). The dispersion of GM seeds may occur during the sowing, harvesting and transportation. In addition, biotic, such as birds and fishes, and abiotic, such as wind and water, can carry the GM seed to long distances (EASTHAM \& SWEET, 2002). In the scenario of transgenic herbicide resistant crop, the dispersion of the GM gene to a relative weed could result in "super weeds", as this acquired the herbicide resistance gene (CHEN et al., 2004).

In environment there are a number of examples of crops and relatives weeds with reproductive compatibility, such as wheat (Triticum aestivum) and Aegilops cylindrica, canola (Brassica napus) and wild mustard (B. rapa), oat (Avena strigosa) and wild oat (A. barbata), sugar beets (Beta vulgaris ssp. vulgaris) and sea beets (B. vulgaris ssp. maritima), sorghum (Sorghum bicolor) and $\boldsymbol{S}$. propinquun and cultivated rice (Oryza sativa) and weedy red rice ( $\boldsymbol{O}$. sativa) (ELLSTRAND et al., 1999; ELLSTRAND \& SCHIERENBECK, 2000; GRESSEL, 2000; ARNAUD et al., 2003). The introgression of glyphosate tolerant gene from GM canola has been reported in other brassicas wild plants (WARWICK et al., 2008). One of the most important examples of gene flow between crop and weed occurs with the natural mutant rice tolerant to imidazolinones herbicides $\left(\right.$ Clearfield $\left.{ }^{\circledR}\right)$ to weedy red rice. After three to four seasons of cultivation of rice resistant to these herbicides, a large number of weedy rice populations were reported as resistant to imidazolines herbicides as a consequence of gene flow from cultivated rice (ZHANG et al., 2006; SHIVRAIN et al., 2009; ROSO et al., 2010; GOULART at al., 2014). Gene flow between crops and weeds is a limitation for the development of transgenic technologies. This does not happen in other plants of agricultural importance such as soybean, cotton and corn, since few wild species are sexually compatible in the regions where these crops are cultivated (GRESSEL, 2000).

Various mitigation and containment strategies of transgene flow are suggested in the literature, such as male sterility (WEIDER et al., 2009), gene silencing via RNAi (LI et al., 2008), cleistogamy (YOSHIDA et al., 2007) and GURTs (HILLS et al., 2007; VAN ACKER et al., 2007; LOMBARDO, 2014). Limitation of using male sterility, gene silencing and cleistogamy is because they are not completely effective and some gene flow can still occur. The GURT will result in the production of sterile seeds, eliminating the problem associated with the dispersion of the GM trait during harvest or transportation; and therefore, containing the gene flow to relative species (GRESSEL \& VALVERDE, 2009; SANG et al., 2013).

Some possible problems are pointed in the use of GURTs to contain the gene flow. In T-GURT, in seed production areas where external inductor is not applied the gene flow can occur and these plants could serve as transgenes source for relative weeds (GRESSEL \& VALVERDE, 2009). In addition, in seed production areas, the three components of V-GURT construct should always remain linked together, without segregating. If the segregation occurs, the V-GURT construct lose functionality and result on the suicide of plants grown from seeds that do not carry the repressor gene because the terminator gene will be expressed. Furthermore, the functionality of the external inducer must be effective in all plants in order to avoid the dispersion of the GM trait. Finally, the LEA promoter may be silenced resulting in absence of RIP (toxic to the embryo) production (DANIELL, 2002). In this situation the seeds will be viable and these plants could be source of gene flow to other relative weeds.

\section{Management of volunteer plants of GM crops}

Approximately $80 \%$ of the cultivated area with genetically modified crops refers to the cultivars with tolerance to herbicides, especially glyphosate (DUKE \& POWLES, 2009). In fields cultivated with herbicide resistant crops, volunteer plants originated from grain losses during harvest or from natural seed decay results in problems for the next crop season. Plants originated from this seeds will not be controlled by the herbicide commonly used, competing with the crop and resulting in yield losses (MARQUARDT et al., 2012). An example of this problem is the effect of volunteer GR corn on GR soybean crop, or vice versa, because the herbicide used in both crops is glyphosate. In that situation, the use of other herbicides or control method to replace glyphosate is required to control the volunteer transgenic plants (DEEN et al, 2006; BOND \& WALKER, 2009). However, several herbicide resistance genes have been stacked into the same crop genotype, reducing herbicide options for the management of volunteer plants (SOLTANI et al., 2014). The V-GURT technology could be employed to prevent the occurrence of volunteer plants. In that situation, the seeds that remain on the soil as a result of natural decay or harvest losses will not be able to germinate.

This technology could also be used in the management of cover crops in no-tillage systems. In addition to other advantages, cover crops play 
an important role in weed control, since areas with a reasonable amount of coverage have lower germination of unwanted plants. However, cover crops need to be managed, which is performed primarily by using herbicides. The use of GURTs could replace the herbicide use in these situations, reducing production costs and undesirable environmental effect caused by herbicides. The procedure for using GURTs will be related with the use of a specific promoter with a lethal gene to plants, which would be expressed during flowering of cover crop plants. Thus, cover crops will commit "suicide" at the time of flowering, just when is the largest dry matter accumulation and weed suppression is already established.

\section{Management of insects and diseases}

The remain of host plants during the off-season allows insects to feed and reproduce, maintaining a high population in the next season (SUMMERS et al., 2004). In certain producing regions of Brazil, it is mandatory the removal of cotton plants during certain periods in order to reduce the occurrence of insects, such as host boll weevil (Anthomonus grandis), the main pest of this crop. The efficiency of this procedure is limited at some locations. With the use of GURTs the occurrence of volunteer plants from seed lost during the harvest or transportation would not occur.

Some GM cultivars are herbicide and insect tolerant. Volunteer $B t$ corn plants had been more sensitive to attack by pests, which survive the action of Cry proteins, favoring the selection of resistant individuals (KRUPKE et al., 2009; MARQUARDT et al., 2013). The main reason given for the survival of insects is that these plants have lower levels of Cry protein, allowing the survival of some individuals. Causes of lower Cry protein production would be the absence of nitrogen fertilization on soybean, which would result in nitrogen deficient corn plants with lower protein synthesis, including the Cry proteins (KRUPKE et al., 2009; MARQUARDT et al., 2013).

The presence of volunteer plants is also important for dissemination of pathogens, such as Phakopsora pachyrhizi, the causal agent of the asian soybean rust (ASR). The ASR is responsible for soybean losses of 10-80\% (SCHNEIDER, et al., 2005 ), and one of the main problems of soybean worldwide, associated with high production cost due to the requirement of fungicides application to control ASR. Presence of host, along with the presence of ASR spores and favorable environmental conditions are necessary to the epidemic development of $\boldsymbol{P}$ pachyrhizi (YORINORI et al., 2005). Thus, the reduction of inoculums by a sanitary empty period is important for the prevention and management of ASR (MORALES et al., 2012). Currently, in almost all soybean-producing areas of Brazil, legislation requires periods of at least 60 days with the absence of soybean plants in fields. Therefore, V-GURT technology could also contribute for the prevention of fungi dispersion and decrease the disease evolution.

The V-GURT would reduce or even eliminate the presence of host plants during the offseason, been an additional tool for the integrated pest management. As a consequence, the adequate sanitary empty would be an automatic practice in fields that used V-GURT seeds. In addition to advantages related to lower incidence of insects and diseases due to absence of host, it would be also effective to maintain the effectiveness of the transgenic technologies, preventing the resistance.

\section{CONCLUSION}

Initially developed to protect intellectual property to the GM crops, knowledge of GURTs opens new horizons related to the potential of its use. Although the social, economic and food safety issues are the main constrains to be analyzed for the deregulation of GURTs, the technical applications other than intellectual property rights should be analyzed. In the situations of GURTs approval it is important to consider the requirements for effectiveness of the benefits that this technology could have for weed, insect pests and disease control.

Production of non-viable seeds through GURTs can be used in the prevention of gene flow between conspecific plants, avoiding the generation of "super weeds". Management of cover crops can also be benefited with GURT resulting in the autonomous plant death in the flowering stage eliminating the requirement for herbicide use. The production of V-GURT seeds also aid in the management of insect pests and diseases by preventing the formation of a "green bridge" between crops. These benefits would result in the reduction of pesticide use, which is economically and environmentally desirable.

One of the main claims against the marketing of GURT technology is that the producers would become dependent on the multinational holding technology, since the seeds produced are not viable for the next crop season. It is important to emphasize the necessities for the availability of other crop varieties for farmers that do not want to use GM traits. In addition, it is important also communicate with farmers in order to do the correct identification of 
crop varieties and management procedures according with their overall technologies in order to avoid unnecessary expenditures, including the possibility of using their correctly produced own seed. Finally is important to emphasize that rigorous studies on the possible impacts of GURTs must be conducted before the technology be used advisedly.

\section{ACKNOWLEDGEMENTS}

To professor Ribas Antônio Vidal (UFRGS), for his contributions on this manuscript, and to Conselho Nacional de Desenvolvimento Científico e Tecnológico (CNPq), for scholarship and fellowship given to the first and second authors, respectively.

\section{REFERENCES}

ARNAUD, J.F. et al. Evidence for gene flow via seed dispersal from crop to wild relatives in Beta vulgaris (Chenopodiaceae): consequences for the release of genetically modified crop species with weedy lineages. Proceedings of the Royal Society B: Biological Sciences, v.270, n.1, p.1565-1575, 2003. Available from: <http:// www.ncbi.nlm.nih.gov/pmc/articles/PMC1691408/pdf/12908976. pdf>. Accessed: Jun. 03, 2016. doi: 10.1098/rspb.2003.2407.

BATTAGLIA, M. et al. The enigmatic LEA proteins and other hydrophilins. Plant Physiology, v.148, n.1, p.6-24, 2008. Available from: <http://www.plantphysiol.org/content/148/1/6>. Accessed: Jun. 03, 2016. doi: 10.1104/pp.108.120725.

BATTAGLIA, M.; COVARRUBIAS, A.A. Late Embryogenisis Abundant (LEA) proteins in legumes. Frontiers in Plant Science, v.4, n.1, p.1-11, 2013. Available from: <http://www.ncbi.nlm.nih. gov/pubmed/23805145>. Accessed: Jun. 03, 2016. doi: 10.3389/ fpls.2013.00190.

BIES-ETHÈVE, N. et al. Inventory, evolution and expression profiling of the LEA (Late Embryogenisis Abundant) protein gene family in Arabidopsis thaliana. Plant Molecular Biology, v.67, n.1-2, p.107-124, 2008. Available from: $<$ http://link.springer.com/ article/10.1007\%2Fs11103-008-9304-x>. Accessed: Jun. 03, 2016. doi: $10.1007 / \mathrm{s} 11103-008-9304-\mathrm{x}$.

BOND, J.A.; WALKER, T.W. Control of volunteer glyphosateresistant soybean in rice. Weed Technology, v.23, n.2, p.225-230, 2009. Available from: <http://www.bioone.org/doi/abs/10.1614/ WT-08-156.1? journalCode=wete $>$. Accessed: Jun. 03, 2016. doi: 10.1614/WT-08-156.1.

CHEN, L.J. et al. Gene flow from cultivated rice (Oryza sativa) to its weedy and wild relatives. Annals of Botany, v.93, n.1, p.67-73, 2004. Available from: $<$ http://aob.oxfordjournals.org/content/93/1/67. long $>$. Accessed: Jun. 03, 2016. doi: 10.1093/aob/mch006.

COMISSÃO TÉCNICA NACIONAL DE BIOSSEGURANÇA (CTNBIO). Ata da 174ª Reunião Ordinária da Comissão Técnica Nacional de Biossegurança-CTNBio. 2014. Online. Available from: $<$ http://www. ctnbio.gov.br/upd blob/0002/2006.pdf $>$. Accessed: Jun. 03, 2016.

DANIELL, H. Molecular strategies for gene containment in transgenic crops. Nature Biotechnology, v.20, n.1, p.581-587, 2002. Available from: <http://www.nature.com/nbt/journal/v20/n6/abs/nbt0602-581. html>. Accessed: Jun. 03, 2016. doi: 10.1038/nbt0602-581.
DEEN, W. et al. Control of volunteer glyphosate-resistant corn (Zea mays) in glyphosate-resistant soybean (Glycine max). Weed Technology, v.20, n.1, p.261-266, 2006. Available from: <http:// www.bioone.org/doi/pdf/10.1614/WT-02-128.1>. Accessed: Jun. 03, 2016. doi: 10.1614/WT-02-128.1.

DUKE, S.O.; POWLES, S.B. Glyphosate-resistant crops and weeds: now and in the future. AgBioForum, v.12, n.3-4, p.346-357, 2009. Available from: <http://naldc.nal.usda.gov/download/40555/ PDF>. Accessed: Jun. 03, 2016.

EASTHAM, K.; SWEET, J. Genetically Modified Organisms (GMOs): the significance of gene flow through pollen transfer. Copenhagen, Denmark: European Environmental Agency, 2002. 75p. (Environmental Issue Report 28) Online. Available from: $<$ http://www.eea.europa.eu/publications/environmental_issue_ report_2002_28>. Accessed: Jun. 03, 2016.

ECONEXUS AND THE FEDERATION OF GERMAN SCIENTISTS. VGURTs (terminator technology): design, reality and inherent risks, 2006. 16p. Available from: <http://www. econexus.info/sites/econexus/files/ENx-CBD-GURTs-2006 0. pdf $>$. Online. Accessed: Jun. 03, 2016.

ELLSTRAND, N.C. et al. Gene flow and introgression from domesticated plants into their wild relatives. Annual Review of Ecology and Systematics, v.30, n.1, p.539-563, 1999. Available from: $<\mathrm{http} / /$ www.annualreviews.org/doi/abs/10.1146/annurev.ecolsys.30.1.539>. Accessed: Jun. 03, 2016. doi: 10.1146/annurev.ecolsys.30.1.539.

ELLSTRAND, N.C.; SCHIERENBECK, K.A. Hybridization as a stimulus for the evolution of invasiveness in plants? PNAS, v.97, n.13, p.7043-7050, 2000. Available from: <http://www.pnas.org/content/97/13/7043.full>. Accessed: Jun. 03, 2016. doi: 10.1073/pnas.97.13.7043.

GOULART, I.C.G.R. et al. Distribution of weedy red rice (Oryza sativa) resistant to imidazolinone herbicides and its relationship to rice cultivars and wild Oryza species. Weed Science, v.62, n.2, p.280-293, 2014. Available from: <http://www.bioone.org/doi/ abs/10.1614/WS-D-13-00126.1>. Accessed: Jun. 03, 2016. doi: 10.1614/WS-D-13-00126.1.

GOULART, I.C.G.R. et al. Identification of origin and analysis of population structure of field-selected imidazolinone-herbicide resistant red rice (Oryza sativa). Euphytica, v.187, n.3, p.437-447, 2012. Available from: <http://link.springer.com/article/10.1007\% 2Fs10681-012-0738-5>. Accessed: Jun. 03, 2016. doi: 10.1007/ s10681-012-0738-5.

GRESSEL, J. Molecular biology of weed control. Transgenic Research, v.9, n.4-5, p.355-382, 2000. Available from: <http:// www.ncbi.nlm.nih.gov/pubmed/11131013>. Accessed: Jun. 03, 2016. doi: 10.1023/A:1008946628406.

GRESSEL, J.; VALVERDE, B.E. A strategy to provide longterm control of weedy rice while mitigating herbicide resistance transgene flow, and its potential use for other crops with related weeds. Pest Management Science, v.65, n.7, p.723-731, 2009. Available from: <http://dx.doi.org/10.1002/ps.1754>. Accessed: Jun. 03, 2016. doi: 10.1002/ps.1754.

HILLS, M. J. et al. Genetic use restriction technologies (GURTs): strategies to impede transgene movement. Trends in Plant Science, v.12, n.4, p.177-183, 2003. Available from: $<$ http://www. cell.com/trends/plant-science/abstract/S1360-1385(07)00038-6>. Accessed: Jun. 03, 2016. doi: 10.1016/j.tplants.2007.02.002. 
KRUPKE, C. et al. Volunteer corn presents new challenges for insect resistance management. Agronomy Journal, v.101, n.3, p.797-799, 2009. Available from: <https://extension.entm.purdue. edu/fieldcropsipm/pubs/1.pdf $>$. Accessed: Jun. 03, 2016. doi: 10.2134/agronj2008.0149Nx.

LEDFORD, L. Seed-patent case in Supreme Court. Nature, v.494, n.7437, p.289-290, 2013. Available from: <http://www nature.com/news/seed-patent-case-in-supreme-court-1.12445>. Accessed: Jun. 03, 2016. doi: 10.1038/494289a.

LEHMANN, V. Patent on seed sterility threatens seed saving. Biotechnology and Development Monitor, v.35, n.1, p.6-8, 1998. Available from: <http://www.biotech-monitor.nl/new/index. php?link=publications $>$. Accessed: Jun. 03, 2016.

LI, C. et al. A built-in strategy for containment of transgenic plants: creation of selectively terminable transgenic rice. Plos One, v.3, n.1, p.1-6, 2008. Available from: <http://dx.plos.org/10.1371/ journal.pone.0001818>. Accessed: Jun. 03, 2016. doi: 10.1371/ journal.pone.0001818.

LOMBARDO, L. Genetic use restriction technologies: a review. Plant Biotechnology Journal, v.12, n.8, p.995-1005, 2014. Available from: <http://onlinelibrary.wiley.com/doi/10.1111/ pbi.12242/epdf>. Accessed: Jun. 03, 2016. doi: 10.1111/pbi.12242.

MARQUARDT, P. et al. Competition of transgenic volunteer corn with soybean and the effect on western corn rootworm emergence. Weed Science, v.60, n.2, p.193-198, 2012. Available from: <http:// www.bioone.org/doi/pdf/10.1614/WS-D-11-00133.1>. Accessed: Jun. 03, 2016. doi: 10.1614/WS-D-11-00133.1.

MARQUARDT, P. et al. The impact of volunteer corn on crop yields and insect resistance management strategies. Agronomy, v.3, n.1, p.488-496, 2013. Available from: <http://www.oalib.com/ paper/3089996\#.V1I6ivkrLIU>. Accessed: Jun. 03, 2016. doi: 10.3390/agronomy3020488.

MORALES, A.M.A.P. et al. Advances on molecular studies of the interaction soybean - Asian rust. Crop Breeding and Applied Biotechnology, v.12, n.1, p.1-7, 2012. Available from: $\quad<$ http://www.scielo.br/scielo.php?script=sci_arttext\&pid $=$ S1984-70332012000100001>. Accessed: Jun. 03, 2016. doi: 10.1590/S1984-70332012000100001

NIILER, E. Terminator technology temporarily terminated. Nature Biotechnology, v.17, n.11, p.1054, 1999. Available from: <http:// www.nature.com/nbt/journal/v17/n11/full/nbt1199_1054.html>. Accessed: Jun. 03, 2016. doi: 10.1038/15034.

OLIVER, M.J. et al. United States Patent no. 5,723,765. Control of plant gene expression. United States Patent and Trademark Office. 1998. Available from: <http://patft.uspto. gov/netacgi/nph-Parser?Sect $1=$ PTO $1 \&$ Sect $2=$ HITOFF \& $\mathrm{d}=$ PALL \& $\mathrm{p}=1 \& \mathrm{u}=\% 2$ Fnetahtm $1 \% 2 \mathrm{FPTO} \% 2 \mathrm{Fsrchnum}$. $\mathrm{htm} \& \mathrm{r}=1 \& \mathrm{f}=\mathrm{G} \& \mathrm{l}=50 \& \mathrm{~s} 1=5723765 . \mathrm{PN} . \& \mathrm{OS}=\mathrm{PN} / 5723765 \& \mathrm{RS}$ $=$ PN/5723765 $>$. Accessed: Jun. 03, 2016.

PENDLETON, C.N. The peculiar case of "Terminator" Technology: agricultural biotechnology and intellectual property protection at the crossroads of the third Green Revolution. Biotechnology Law Report, v.23, n.1, p.1-29, 2004. Available from: <http://online.liebertpub.com/doi/abs/1 0.1089/073003104322838222>. Accessed: Jun. 03, 2016. doi: $10.1089 / 073003104322838222$.
ROSO, A.C. et al. Regional scale distribution of imidazolinone herbicide-resistant alleles in red rice (Oryza sativa L.) determined through SNP markers. Field Crops Research, v.119, n.2, p.175182, 2010. Available from: <http://www.sciencedirect.com/ science/article/pii/S0378429010001759>. Accessed: Jun. 03, 2016. doi: $10.1089 / 073003104322838222$.

SANG, Y. et al. Gene use restriction technologies for transgenic plant bioconfinement. Plant Biotechnology Journal, v.11, n.6, p.649-658, 2013. Available from: <http://onlinelibrary.wiley. com/doi/10.1111/pbi.12084/epdf>. Accessed: Jun. 03, 2016. doi: 10.1111/pbi.12084.

SCHNEIDER, R.W. et al. First report of soybean rust caused by Phakopsora pachyrhizi in the continental United States. Plant Disease, v.89, n.1, p.774-774, 2005. Available from: <http:// apsjournals.apsnet.org/doi/abs/10.1094/PD-89-0774A > . Accessed: Jun. 03, 2016. doi: 10.1094/PD-89-0774A.

SHEORAN, I.S. et al. Proteome profile and functional classification of proteins in Arabidopsis thaliana (Landsberg erecta) mature pollen. Sexual Plant Reproduction, v.14, n.4, p.185-196, 2006. Available from: <http://link.springer.com/ article/10.1007/s00497-006-0035-3>. Accessed: Jun. 03, 2016. doi: $10.1007 / \mathrm{s} 00497-006-0035-3$.

SHIVRAIN, V.K. et al. Gene flow from weedy red rice (Oryza sativa L.) to cultivated rice and fitness of hybrids. Pest Management Science, v.65, n.10, p.1124-1129, 2009. Available from: <http://onlinelibrary.wiley.com/doi/10.1002/ps.1802/epdf>. Accessed: Jun. 03, 2016. doi: 10.1002/ps.1802.

SOLTANI, N. et al. Volunteer glyphosate and glufosinate resistant corn competitiveness and control in glyphosate and glufosinate resistant corn. Agricultural Sciences, v.5, n.5, p.402-409, 2014. Available from: <http://file.scirp.org/pdf/ AS 2014040911534214.pdf>. Accessed: Jun. 03, 2016. doi: 10.4236/as.2014.55042.

SUMMERS, C.G. et al. Overwintering of corn leafhopper, Dalbulus maidis (Homoptera: Cicadellidae), and Spiroplasma kunkelii (Mycoplasmatales: Spiroplasmataceae) in California's San Joaquin Valley. Environmental Entomology, v.33, n.1, p.1644-1651, 2004. Available from: <http://www.bioone.org/doi/ pdf/10.1603/0046-225X-33.6.1644>. Accessed: Jun. 03, 2016. doi: $10.1603 / 0046-225 X-33.6 .1644$.

VAN ACKER, R.C. et al. The potential benefits, risks and costs of genetic use restriction technologies. Canadian Journal of Plant Science, v.87, n.4, p.753-762, 2007. Available from: $<$ http://www. nrcresearchpress.com/doi/pdf/10.4141/CJPS06033>. Accessed: Jun. 03, 2016. doi: 10.4141/CJPS06033.

WARWICK, S.I. et al. Do escaped transgenes persist in nature? The case of an herbicide resistant transgene in a weedy Brassica rapa population. Molecular Ecology, v.17, n.5, p.1387-1395, 2008. Available from: <http://onlinelibrary.wiley.com/doi/10.1111/ j.1365-294X.2007.03567.x/epdf $>$. Accessed: Jun. 03, 2016. doi: 10.1111/j.1365-294X.2007.03567.x

WARWICK, S.I. et al. Gene flow, invasiveness, and ecological impact of genetically modified crops. Annals of the New York Academy of Sciences, v.1168, n.1, p.72-99, 2009. Available from: <http://onlinelibrary.wiley.com/doi/10.1111/j.17496632.2009.04576.x/pdf>. Accessed: Jun. 03, 2016. doi: 10.1111/j.1749-6632.2009.04576.x. 
WEIDER, C. et al. Stability of cytoplasmic male sterility in maize under different environmental conditions. Crop Science, v.49, n.1, p.77-84, 2009. Available from: <https://dl.sciencesocieties. org/publications/cs/pdfs/49/1/77>. Accessed: Jun. 03, 2016. doi: 10.2135/cropsci2007.12.0694.

YORINORI, J.T. et al. Epidemics of soybean rust (Phakopsora pachyrhizi) in Brazil and Paraguay from 2001 to 2003. Plant Disease, v.89, n.6, p.675-677, 2005. Available from: <http:// apsjournals.apsnet.org/doi/pdf/10.1094/PD-89-0675>. Accessed: Jun. 03, 2016. doi: 10.1094/PD-89-0675.
YOSHIDA, H. et al. superwoman 1-cleitogamia, a hopeful allele for gene containment in GM rice. Plant Biotechnology Journal, v.5, n.6, p.835-846, 2007. Available from: <http://onlinelibrary. wiley.com/doi/10.1111/j.1467-7652.2007.00291.x/epdf $>$. Accessed: Jun. 03, 2016. doi: 10.1111/j.1467-7652.2007.00291.x.

ZHANG, W. et al. Risk assessment of the transfer of imazethapyr herbicide tolerance from Clearfield rice to red rice (Oryza sativa). Euphytica, v.152, n.1, p.75-86, 2006. Available from: $<$ http://link. springer.com/article/10.1007\%2Fs10681-006-9180-x>. Accessed: Jun. 03, 2016. doi: 10.1007/s10681-006-9180-x. 